\title{
Foamy Gland Variant of Prostatic Carcinoma
}

\section{Prostatik Adenokarsinom Köpüksü Gland Varyant}

\section{Sevdegül Mungan, Ümit Çobanoğlu}

Karadeniz Teknik University Faculty of Medicine, Department of Pathology, Trabzon, Turkey

\section{Introduction}

The foamy gland variant (FGV) of prostatic acinar adenocarcinoma was first described by Nelson and Epstein (1) in 1996. Abundant xanthomatous cytoplasm with picnotic nuclei is characteristic for this variant. The FGV is uncommon but its incidence is not clear on transurethral resection materials (2). The age range of affected patients with foamy gland carcinoma does not differ from that of those with the usual prostatic adenocarcinoma.

The level of serum prostate-specific antigen (PSA) can be normal or elevated. An indurated nodule can be evaluated by digital rectal examination or hypoechoic lesions by ultrasonography (3).

The histomorphological findings are crowded or infiltrating glands with abundant xanthomatous cytoplasm and small inconspicuous nucleoli (Figure 1). Most of them are with Gleason score $6(3+3)$, and the glands are well formed. But Gleason score may be higher $(3+4,4+4)$ if architectural patterns of cribriform, fused, and poorly formed glands, cords, single cells or solid sheets are observed (Figure 2). Nuclei are commonly enlarged in higher patterns.

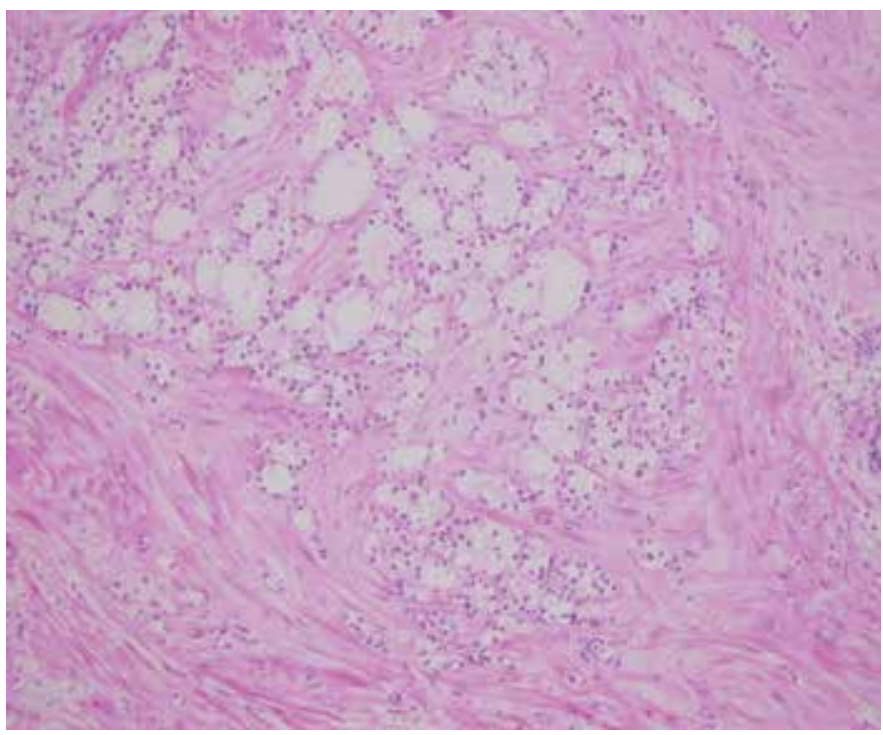

Figure 1. Foamy gland carcinoma with crowded glands containing abundant cytoplasm
Nucleoli can be prominent or mitotic figures may be observed (4). There can be associated usual or foamy gland high grade prostatic intraepithelial neoplasia. There can be coexistence of FGV and usual acinar adenocarcinoma (3).

Some special studies (immunohistochemistry and molecular diagnostics) may support the diagnosis. PSA and prostate-specific acid phosphatase are always positive (Figure 3), alpha-methylCoA-racemase is commonly positive (Figure 4), basal cell markers (p63, HMWCK) are negative or patchy immunohistochemically in higher grade cancers. In 29\% of cases, the fusion of TMPRSS-ERG is present (5).

The pitfalls in differential diagnosis are benign glands, mucinous metaplasia and Cowper's glands. Malign glands of foamy gland cancer have numerous dense, pink amorphous secretions and rounded corpora with concentric rings further distinguish foamy gland carcinoma from benign glands. Mucin stains are strongly positive in mucinous metaplasia and they are negative in FGV of prostatic adenocarcinoma. This differentiation marker also applies to Cowper glands. They have cytoplasmic mucin (3).

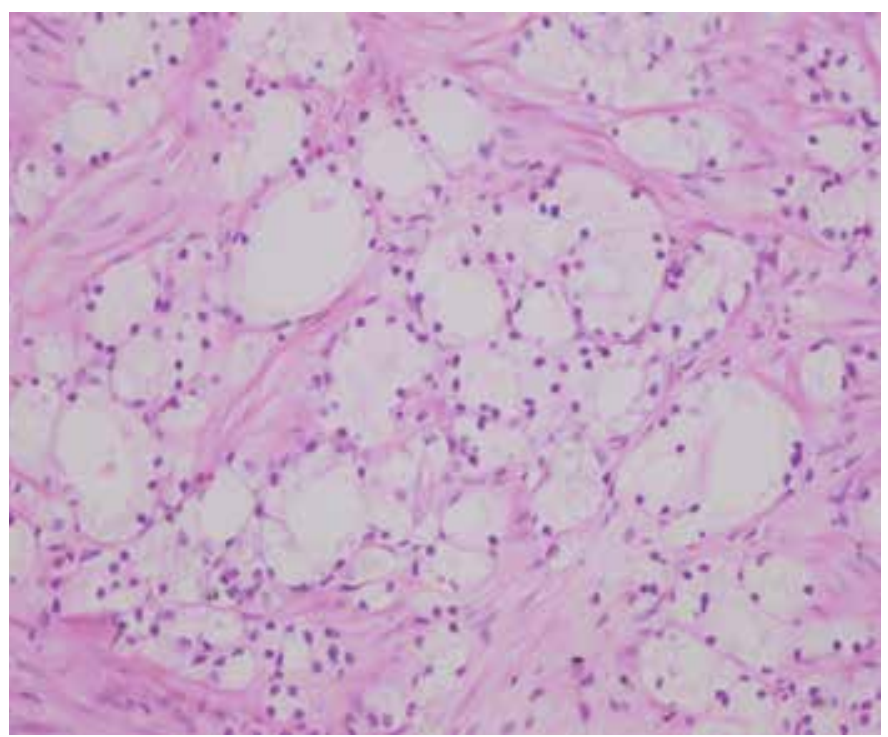

Figure 2. Cribriform higher grade of foamy gland carcinoma

\section{Correspondence}

Sevdegül Mungan MD, Karadeniz Teknik University Faculty of Medicine, Department of Pathology, Trabzon, Turkey E-mail: drsevdegul@gmail.com Received: 10.11.2015 Accepted: 10.11.2015 


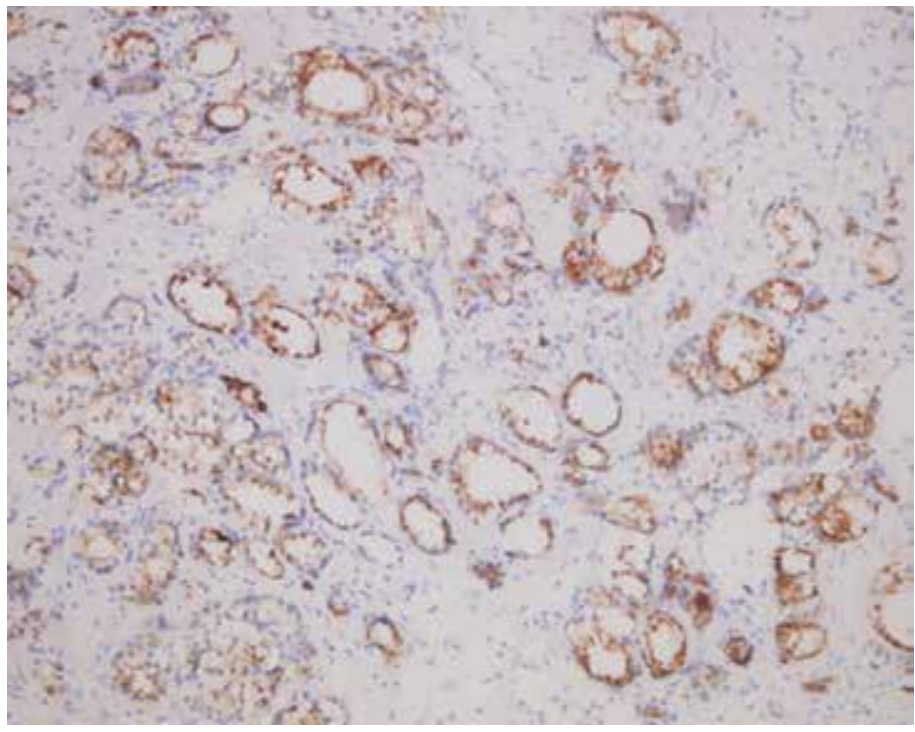

Figure 3. Prostate-specific antigen positivity in neoplastic cells

The prognosis of the FGV of prostatic adenocarcinoma depends on Gleason score and stage at presentation. They are not low-grade despite deceivingly benign histologic appearance.

Treatment modalities are similar to those for usual acinar adenocarcinoma (radical prostatectomy, radiotherapy, hormone ablation therapy) (5).

\section{Keywords: Prostate, adenocarcinoma, foamy gland}

Anahtar Kelimeler: Prostat, adenokarsinom, köpüksü bez

\section{Authorship Contributions}

Informed Consent: Sevdegül Mungan, Ümit Çobanoğlu, Concept: Sevdegül Mungan, Design: Sevdegül Mungan, Ümit Çobanoğlu, Data Collection or Processing: Sevdegül Mungan, Analysis or Interpretation: Sevdegül Mungan, Literature Search: Sevdegül Mungan, Writing: Sevdegül Mungan, Peer-review: Internal peer-reviewed, Conflict of Interest: No conflict of interest was declared by the authors, Financial

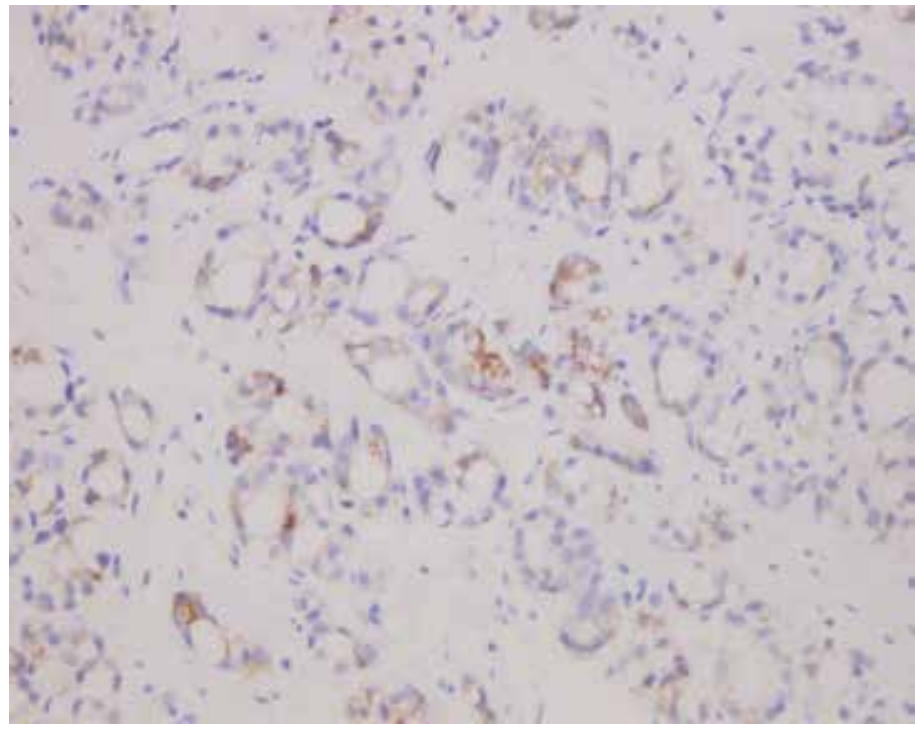

Figure 4. Neoplastic glands with focal alpha-methyl-CoA-racemase positivity

Disclosure: The authors declared that this study has received no financial support.

\section{References}

1. Nelson RS, Epstein Jl. Prostatic carcinoma with abundant xanthomatous cytoplasm: foamy gland carcinoma. Am J Surg Pathol 1996;20;419-426.

2. Hudson J, Cao D, Vollmer R, Kibel AS, Grewal S, Humphrey PA. Foamy gland adenocarcinoma of the prostate: incidence, Gleason grade, and early clinical outcome. Hum Pathol 2012;43;974-979.

3. Zhou M, Netto GJ, Epstein JI. Uropathology in neoplastic disease of the prostate. 1st ed. Philedelphia, Elsevier, 2012, pp 66-67.

4. Zhao J, Epstein Jl. High-grade foamy gland prostatic adenocarcinoma on biopsy or transurethral resection: a morphologic study of 55 cases. Am J Surg Pathol 2009;33;583-590.

5. Warric $\mathrm{Jl}$, Humphrey PA. Foamy gland carcinoma of the prostate in needle biopsy: incidence, Gleason grade, and comparative alpha-methylacylCoA Racemase vs. ERG expression. Am J Surg Pathol 2013;37;1709-1714. 